\title{
JUBILEUSZ 90-LECIA UNIWERSYTETU EKONOMICZNEGO W POZNANIU
}

\section{PODSTAWOWE INFORMACJE O UCZELNI ANNO DOMINI 2016}

Uniwersytet Ekonomiczny w Poznaniu jest trzecią pod względem czasu istnienia polską uczelnią ekonomiczna. Najstarszą polską wyższą uczelnią ekonomiczna jest dzisiejsza Szkoła Główna Handlowa w Warszawie, która powstała jako Prywatne Kursy Handlowe Męskie Augusta Zielińskiego w 1906 r. Drugi pod względem wieku jest Uniwersytet Ekonomiczny w Krakowie, założony wiosną 1925 r. jako Wyższe Studium Handlowe. Tylko o kilkanaście miesięcy młodszy Uniwersytet Ekonomiczny w Poznaniu powstał w 1926 r. pod nazwa Wyższa Szkoła Handlowa jako uczelnia prywatna, powołana przez Izbę Przemysłowo-Handlową w Poznaniu oraz Kuratorium Okręgu Szkolnego Poznańskiego. Misją powstałej kilka lat po zakończeniu I wojny światowej Uczelni było kształcenie kadr dla odradzającej się gospodarki polskiej, a w szczególności wielkopolskiej. Prace nad powołaniem Uczelni rozpoczęto w 1925 r., ale formalny początek funkcjonowania oznaczała inauguracja pierwszego roku akademickiego 12 października 1926 r. W inauguracji uczestniczył minister przemysłu i handlu w rządzie Kazimierza Bartla - Eugeniusz Kwiatkowski. Uczelnia posiada status akademicki od 1938 r., kiedy to uzyskała prawo do nadawania stopnia magistra i zmieniła nazwę na Akademia Handlowa. W 1950 r. Akademię Handlową znacjonalizowano i zmieniono jej nazwę na Wyższa Szkoła Ekonomiczna. W 1974 r. Uczelnię przemianowano na Akademię Ekonomiczną w Poznaniu, a 27 grudnia 2008 r. Uczelnia przekształciła się w Uniwersytet Ekonomiczny w Poznaniu.

W 2016 r. Uczelnia zatrudnia 966 pracowników ogółem, w tym 520 nauczycieli akademickich, spośród których 175 to samodzielni pracownicy nauki. W murach Uniwersytetu kształci się na studiach stacjonarnych i niestacjonarnych I i II stopnia ok. 10,5 tys. studentów, bez mała 500 doktorantów (stacjonarni, niestacjonarni oraz środowiskowi) i ok. 1400 słuchaczy studiów podyplomowych. Całkowita liczba studiujaccych obcokrajowców wynosi około 350 osób, w tym na studiach całościowych - około 200 osób, a około 150 osób na studiach częściowych (Erasmus, umowy bilateralne). Z kolei w minionym roku akademickim 2015/2016 ponad 220 studentów UEP wy- 
jechało za granicę (studia, praktyki). Dzisiaj UEP oferuje nie tylko studia I i II stopnia, ale również studia doktoranckie, zajęcia dla osób dorosłych w ramach Uniwersytetu III Wieku - Erga Omnes oraz dla najmłodszych, którzy chętnie uczestniczą w programie Ekonomiczny Uniwersytet Dziecięcy i Akademia Młodego Ekonomisty. Osobom, które chciałyby uzupełnić swoje wykształcenie, Uczelnia oferuje studia podyplomowe w Centrum Edukacji Menedżerskiej. Na podkreślenie zasługuje prężny rozwój studiów anglojęzycznych. W roku akademickim 2011/2012 uruchomiono m.in. program Doctoral Seminars in English, w całości prowadzony w języku angielskim. Uczelnia współpracuje na polu naukowym i dydaktycznym z prawie 200 uniwersytetami z całego świata.

O pozycji Uczelni świadczą przyznane akredytacje krajowe: Polskiej Komisji Akredytacyjnej, Fundacji Promocji i Akredytacji Kierunków Ekonomicznych, a także zagraniczne: jedna z najbardziej prestiżowych i cenionych w obszarze edukacji menedżerskiej - CEEMAN, równie wartościowa akredytacja EPAS - dla programu Executive MBA i AMBA - także dla prowadzonego programu MBA. We wrześniu 2016 r. odbyła się na UEP wizyta Komisji Akredytacyjnej z European Foundation for Management Development w sprawie uzyskania akredytacji EQUIS. Wyniki będą znane w grudniu 2016 r. Każdego roku UEP plasuje się wysoko w publikowanych rankingach. W minionym roku akademickim Uniwersytet utrzymał drugą pozycję w ogólnopolskim rankingu „Perspektyw” w kategorii uczelni ekonomicznych. UEP zdobył też drugie miejsce w konkursie na „Najbardziej Prodoktorancką Uczelnię PRODOK” wśród wszystkich polskich uczelni oferujacych studia doktoranckie. W minionych latach w konkursie PRODOK Uczelnia trzy razy zajmowała pierwsze miejsce $\mathrm{i}$ jeden raz trzecie miejsce $\mathrm{w}$ Polsce. $\mathrm{Z}$ kolei na arenie międzynarodowej UEP odnotował sukces w rankingu Eduniversal, w którym awansował do kategorii 4 Palm, uzyskując tym samym tytuł TOP business school with significant international influence. Tytuł ten otrzymuje tylko 200 najlepszych uczelni z całego świata poddawanych ocenie.

W ciagu 90 lat funkcjonowania Uniwersytet nadał dyplomy ukończenia studiów bez mała 96 tys. słuchaczy. Stopień doktora uzyskało około 1340 osób, a stopień doktora habilitowanego - ponad 350 osób. Uczelnia wypromowała także ponad 120 profesorów tytularnych. Liczba absolwentów studiów podyplomowych wynosi prawie 38 tys., w tym ponad 2 tys. kilku realizowanych programów Master of Business Administration (MBA).

\section{OBCHODY ROKU JUBILEUSZOWEGO}

Rok akademicki 2015/2016 był szczególny dla Uniwersytetu Ekonomicznego w Poznaniu - uczelnia świętowała bowiem 90 lat działalności. W kalendarzu obchodów jubileuszowych znalazły się różnorodne wydarzenia, podczas których Uniwersytet odwiedziło wielu znamienitych gości z całego świata. 


\section{Inauguracja rok akademickiego 2015/2016}

Uroczystościa oficjalnie rozpoczynajacca obchody Jubileuszu 90-lecia Uniwersytetu Ekonomicznego w Poznaniu była inauguracja roku akademickiego 2015/2016, która odbyła się w auli UEP 30 września 2015 r. Wykład inauguracyjny pt. „Odkrywanie na nowo dobra wspólnego” wygłosiła prof. dr hab. Małgorzata Słodowa-Hełpa.

\section{85-lecie Stowarzyszenia Absolwentów Uczelni}

Swój jubileusz obchodziło także Stowarzyszenie Absolwentów Uniwersytetu Ekonomicznego w Poznaniu. W murach Uczelni z okazji 85-lecia działalności Stowarzyszenia spotkało się ponad 100 absolwentów. Wśród zaproszonych gości najliczniej stawili się dawni studenci Wyższej Szkoły Ekonomicznej, którzy odebrali odnowione dyplomy z okazji 50-lecia ukończenia studiów.

\section{VIII Dni UEP}

W ramach VIII Dni UEP, które odbyły się w dniach 24-25 lutego 2016 r., zorganizowany został cykl warsztatów oraz debat na temat miastotwórczej roli uniwersytetów. W dyskusji wzięli udział: zastępca prezydenta Miasta Poznania Mariusz Wiśniewski, dyrektor Biura Obsługi Inwestorów Marcin Przyłębski, prezes Nickel Development Dagmara Nickel, architekt Marian Urbański (ATRIUM Autorskie Studio Architektury), plastyk miejski Piotr Libicki, przedstawiciel Centrum Badań Metropolitalnych UAM prof. Tomasz Kaczmarek oraz prof. Wanda Gaczek z Katedry Ekonomiki Przestrzennej i Środowiskowej UEP. Podczas VIII Dni UEP zorganizowany został wernisaż pokonkursowej wystawy plakatów nt. „Dlaczego woda jest tańsza od diamentów?", przygotowanych przez studentów Uniwersytetu Artystycznego w Poznaniu w ramach rozwijanego od kilku lat programu współpracy pomiędzy UEP i UA. W Centrum Edukacyjnym Usług Elektronicznych zaprezentowano 25 prac młodych artystów. Zwieńczeniem VIII Dni UEP była uroczysta gala, podczas której aula Uniwersytetu Ekonomicznego w Poznaniu na jeden wieczór zamieniła się w scenę teatralna. Artyści Teatru Muzycznego w Poznaniu wystawili spektakl pt. „Nie ma jak lata 20., lata 30.”. Podczas Gali VIII Dni UEP pracownicy Uczelni otrzymali odznaczenia państwowe, medale za długoletnia służbę oraz medale za zasługi dla UEP. W trakcie uroczystości wręczono również nagrody Fundacji UEP za najlepsze prace licencjackie, magisterskie i doktorskie oraz stypendium sportowe dla lekkoatletki, uczestniczki finału olimpijskiego w Rio de Janeiro w sztafecie 4x400 m Patrycji Wyciszkiewicz, przyznane przez Radę Programową Klubu Partnera UEP.

\section{Bal Seledynowy}

W ostatnią sobotę karnawału 6 lutego 2016 r. odbył się coroczny Bal Seledynowy. Korzenie balu sięgaja 1933 r. W tym roku zabawa odbyła się w konwencji karnawału w Rio de Janeiro. Bal miał charakter charytatywny - zebrane 
fundusze przeznaczone zostały na wsparcie inicjatyw edukacyjnych i pomocowych organizowanych przez Fundację Akademicką Gaudeamus Igitur na rzecz studentów uczelni poznańskich.

\section{Konferencje naukowe}

Integralną częścią wydarzeń jubileuszowych na Uniwersytecie Ekonomicznym w Poznaniu były liczne konferencje naukowe.

$\mathrm{Na}$ temat strategii rozwoju imprez biegowych debatowano w murach UEP podczas III Ogólnopolskiej Konferencji Metodycznej, zorganizowanej przez Katedrę Strategii Marketingowych 22 i 23 października 2015 r. W konferencji udział wzięło blisko 120 zaproszonych gości z całego kraju - prelekcje wygłosili m.in.: dyrektor Poznań Maratonu Łukasz Miadziołko, dyrektor Wrocław Maratonu Wojciech Gęstwa i dziennikarz sportowy TVP Przemysław Babiarz. Wydarzenie swoim patronatem objęło Polskie Naukowe Towarzystwo Marketingu.

O strategicznym wymiarze dynamicznych zdolności polskich przedsiębiorstw dyskutowali uczestnicy ogólnopolskiej konferencji (10-12 listopada 2015 r.), zorganizowanej od przez Katedrę Teorii Organizacji i Zarządzania UEP oraz Towarzystwo Naukowe Organizacji i Kierownictwa w Poznaniu. W konferencji pt. „Strategiczny wymiar dynamicznych zdolności polskich przedsiębiorstw" udział wzięli naukowcy reprezentujący wszystkie najważniejsze uniwersytety ekonomiczne w Polsce: Uniwersytet Ekonomiczny w Katowicach, Krakowie, Poznaniu, Wrocławiu, a także warszawską Szkołę Główną Handlową oraz Uniwersytet Gdański.

W dniach 12-13 maja 2016 r. odbyły się III Dni Wydziału Towaroznawstwa. Święto Wydziału Towaroznawstwa zainaugurowała konferencja „Środowisko i technologia w biznesie". W ramach wydarzenia zorganizowano XI Dni Młodych Towaroznawców, podczas których studenci i przedstawiciele kół naukowych zaprezentowali wyniki przygotowanych prac magisterskich i inżynierskich. Podczas XII Forum Studenckich Kół Naukowych zaprezentowano 65 prac naukowych, które weszły w skład monografii Młodzi Towaroznawcy 2016. Finałem tegorocznych Dni Wydziału Towaroznawstwa była Sesja Sprawozdawcza Doktorantów UEP. Patronat nad wydarzeniem objęli: JM Rektor UEP prof. dr hab. Marian Gorynia oraz Prezydent Miasta Poznania Jacek Jaśkowiak.

Pracownicy naukowi wszystkich ośrodków naukowych w Polsce oraz przedstawiciele najważniejszych instytucji rynku ubezpieczeniowego wzięli udział w X Międzynarodowej Konferencji Naukowej „Ubezpieczenia wobec wyzwań XXI wieku". Podczas trzydniowego (16-18 maja 2016 r.) wydarzenia odbyło się pięć sesji plenarnych oraz jedna plakatowa. Organizatorem konferencji były Katedra Ubezpieczeń Uniwersytetu Ekonomicznego w Poznaniu oraz Katedra Ubezpieczeń Uniwersytetu Ekonomicznego we Wrocławiu. Patronat honorowy nad wydarzeniem objęli Rektorzy obu Uniwersytetów.

8 czerwca 2016 r. na UEP odbyła się pierwsza konferencja naukowa w Polsce poświęcona równocześnie praktyce funkcjonowania Corporate Social Responsibility (CSR) w instytucjach bankowych, pośrednictwa finansowego i do- 
radztwa finansowego. Organizatorem konferencji „CSR Financial Day 2016. Społeczna odpowiedzialność instytucji finansowych” było Studenckie Koło Naukowe Bankowości i Pośrednictwa Finansowego, działające przy Katedrze Pieniądza i Bankowości. Patronat honorowy nad konferencją objęła Komisja Nadzoru Finansowego i JM Rektor UEP, a patronat merytoryczny - Konferencja Przedsiębiorstw Finansowych w Polsce, Zwiazek Firm Doradztwa Finansowego, Europejska Federacja Doradców Finansowych EFFP Polska, Europejska Akademia Planowania Finansowego, Związek Maklerów i Doradców, Polska Izba Pośredników Ubezpieczeniowych i Finansowych, Związek Firm Pożyczkowych i Fundacja na rzecz Standardów Doradztwa Finansowego EFPA Polska.

Podczas 32. Światowego Kongresu Marketingu - Industrial Marketing and Purchasing Group (IMP) 2016, który odbywał się na Uniwersytecie Ekonomicznym w Poznaniu od 30 sierpnia do 3 września 2016 r., podjęte zostały tematy wchodzenia firm na rynki międzynarodowe, budowania gospodarki opartej na silnych relacjach przedsiębiorstw, a także rozwijania powiązań między biznesem z nauką. W ramach kongresu na Uniwersytecie Ekonomicznym w Poznaniu odbyły się dodatkowo dwa wydarzenia - Business Day oraz Doctoral Colloquium. Uczelnię odwiedziło 220 uczestników z ponad 20 krajów.

II Konferencja Poznańskich Bibliotek Naukowych pod hasłem „Biblioteki, bibliotekarze, zbiory - historia zawsze żywa” odbyła się na UEP 14 września 2016 r. Konferencja poświęcona była historii bibliotek i ich szczególnie cennym zbiorom oraz wspomnieniom o ludziach, którzy na stałe zapisali się w dziejach poznańskiego bibliotekarstwa.

W dniach 16-18 października 2016 r. na UEP zorganizowano XXXV Ogólnopolską Konferencję Naukową im. prof. Władysława Bukietyńskiego. „Metody i Zastosowania Badań Operacyjnych 2016”. Wydarzenie było okazją dla teoretyków i praktyków dyscypliny do wymiany myśli na temat najnowszych osiagnięć dotyczacych metod oraz nowoczesnych zastosowań badań operacyjnych.

Celem International Conference On Accounting, Finance And Financial Institutions. Theory Meets Practice (ICAFFI 2016, 19-21 października 2016 r.) było umożliwienie wymiany doświadczeń i poglądów zarówno środowiska akademickiego, jak i biznesowego w obszarze wyzwań stojących współcześnie przed zarządzającymi podmiotami gospodarczymi.

\section{Wydarzenia sportowe}

Z okazji 90-lecia Uniwersytetu Ekonomicznego w Poznaniu 24 października 2015 r. zorganizowane zostało niecodzienne wydarzenie sportowe - I edycja Biegu po schodach Collegium Altum. Biegacze mieli do pokonania 392 stopnie - meta biegu znajdowała się na 18. piętrze wieżowca. W ramach biegu odbyły się również Mistrzostwa Policji w biegu po schodach pod patronatem Komendanta Miejskiego Policji w Poznaniu insp. Romana Kustera, Mistrzostwa Państwowej Straży Pożarnej oraz Mistrzostwa Polski Studentów i Nauczycieli Akademickich. 
10 kwietnia 2016 r. odbyły się zawody w ramach Ekonomicznej Piątki bieg oraz marsz nordic walking wokół Jeziora Maltańskiego. Podczas VI edycji biegu Volkswagen Ekonomiczna Piątka na starcie pojawiło się 800 biegaczy. W ramach biegu odbyły się również Otwarte Mistrzostwa Wielkopolski w biegu ulicznym. Tuż przed biegiem Volkswagen Ekonomiczna Piątka odbył się Enea Ekonomiczny Marsz Na Piątkę. Uczestnicy marszu mieli do pokonania tę sama trasę, co biegacze - 5 km wokół Jeziora Maltańskiego. Podczas zawodów Rektor UEP prof. dr hab. Marian Gorynia został odznaczony przez Polski Komitet Olimpijski srebrnym medalem „Za zasługi dla Polskiego Ruchu Olimpijskiego”. Patronat honorowy nad zawodami objęli: Prezydent Miasta Poznania Jacek Jaśkowiak oraz Marszałek Województwa Wielkopolskiego Marek Woźniak.

\section{Główne obchody Jubileuszu Uczelni}

Program głównych obchodów 90-lecia Uniwersytetu Ekonomicznego w Poznaniu zakładał zaangażowanie zróżnicowanych grup interesariuszy Uczelni, w tym absolwentów, studentów, pracowników, władz Miasta Poznania i jego mieszkańców oraz wszystkich znakomitych partnerów biznesowych i instytucjonalnych.

13 maja 2016 r. jubileuszowy koncert chóru żeńskiego „Sonantes” z okazji 45-lecia jego powstania otworzył główne obchody Jubileuszu 90-lecia Uniwersytetu Ekonomicznego w Poznaniu. Wydarzenie muzyczne nosiło tytuł „Jak nie my, to kto". Rektor UEP prof. dr hab. Marian Gorynia wręczył chórzystkom okolicznościowe dyplomy. Podczas wydarzenia Rektor UEP wręczył medale i odznaczenia pracownikom UEP. Doktor Szczepan Gawłowski, I wiceprezydent Towarzystwa im. Hipolita Cegielskiego, wręczył pracownikom UEP medale Labor Omnia Vincit oraz medale Młodego Pozytywisty.

Msza Święta z okazji rocznicy utworzenia uczelni ekonomicznej w Poznaniu odbyła się w Katedrze Poznańskiej 15 maja 2016 r. Uroczystości przewodniczył i homilię wygłosił arcybiskup Stanisław Gądecki, metropolita poznański.

Z okazji święta Uczelni przygotowana została wystawa w Centrum Edukacyjnym Usług Elektronicznych oraz na Starym Rynku pt. „Widok na miasto”. Wystawa prezentowała różne formy obecności uczelni w mieście. „Miejsca wspólne" skomentowane są poprzez archiwalne i współczesne fotografie, wspomnienia i osiagnięcia pracowników oraz absolwentów, opowieści o budynkach, osobach i wydarzeniach łączących historię Uczelni i miasta. Rozwinięciem wystawy jest jubileuszowa publikacja pt. „Części składowe. 90 lat Uniwersytetu Ekonomicznego w Poznaniu”.

W trakcie obchodów jubileuszu Uczelni Czytelnia Czasopism w Bibliotece UEP otrzymała imię Hanny Maciejewskiej, która była wieloletnim dyrektorem Biblioteki i zasłużonym bibliografem Uczelni i dorobku jej pracowników. W czytelni otwarta została również wystawa przedstawiająca historię Biblioteki Głównej Uniwersytetu Ekonomicznego w Poznaniu, nieprzerwanie działającej do dzisiaj części składowej ówczesnej Wyższej Szkoły Handlowej. Integralnym elementem ekspozycji jest fragment poświęcony Hannie Maciejewskiej. 
17 maja 2016 r. przy Gmachu Głównym oraz w hali sportowej UEP odbył się Dzień Sportu organizowany przez Klub Uczelniany AZS UEP. Dzień później Parlament Studencki UEP wraz z Radą Uczelnianą Samorządu studenckiego AWF zorganizowali dla żaków festiwal kulturalno-sportowy „Integralia”.

Panel dyskusyjny pt. „Polska gospodarka: osiagnięcia, porażki i szanse rozwojowe" z udziałem: prof. Andrzeja Matysiaka (Uniwersytet Przyrodniczy we Wrocławiu), prof. Witolda Orłowskiego (Politechnika Warszawska), prof. Andrzeja Wojtyny (Uniwersytet Ekonomiczny w Krakowie), prof. Ryszarda Rapackiego (Szkoła Główna Handlowa) oraz prof. Anny Zielińskiej-Głębockiej (Uniwersytet Gdański) odbył się w Centrum Edukacyjnym Usług Elektronicznych 18 maja 2016 r.

19 maja 2016 r. odbyło się uroczyste nadanie tytułu doktora honoris causa Uniwersytetu Ekonomicznego w Poznaniu dr. Andrzejowi Byrtowi. Senat UEP wyróżnił tytułem DHC wybitnego organizatora przedsiębiorczości międzynarodowej, skutecznego lidera biznesu, sprawnego negocjatora i dyplomatę, budowniczego relacji nauki z praktyka, a także uznanego mówcę i propagatora wartości ekonomicznych w społecznościach międzynarodowych. Po uroczystości na Międzynarodowych Targach Poznańskich odbył się spektakl jubileuszowy Polskiego Teatru Tańca pt. „Czterdzieści” (reżyseria, choreografia, scenografia i teksty: Jo Strømgren).

By uczcić pamięć osób zaangażowanych w rozwój Uczelni - pracowników, absolwentów, studentów oraz sympatyków - utworzono specjalną Salę Pamięci. 20 maja 2016 r. otwarto tam wystawę, na której przedstawione zostały dzieje Uniwersytetu od momentu jego powstania do czasów współczesnych.

Główne obchody Jubileuszu 90-lecia Uniwersytetu Ekonomicznego w Poznaniu zakończyło wydarzenie pt. „Wolny targ, czyli wykładamy to, co najlepsze". Ponadto w auli UEP odbył się także koncert chóru Economic Singers pod dyrekcją Magdaleny Szczeniawskiej, który działa przy Otwartej Wszechnicy Ekonomicznej „Erga Omnes”.

\section{Inauguracja 2016/2017 - zakończenie obchodów jubileuszowych}

Pierwsza inauguracja roku akademickiego miała miejsce 12 października 1926 r. Nowy - 91. rok akademicki zainaugurowany został dokładnie 90 lat później: 12 października 2016 r., wieńcząc tym samym obchody Jubileuszu Uczelni. Wykład inauguracyjny pod tytułem „Komercjalizacja kształcenia ekonomistów a dostojeństwo uniwersytetu" wygłosił prof. dr hab. Jan Szambelańczyk.

$$
* * *
$$

Należy podkreślić, że inauguracja roku akademickiego 2016/2017 oznacza jednocześnie rozpoczęcie dekady jubileuszowej, bowiem do 100 lat pozostało już tylko 10. Dekada ta powinna stanowić okazję nie tylko do refleksji nad czasem przeszłym, dokonaniami, osiagnięciami, a być może także niepowodzeniami. Należy mieć je w pamięci, ale nie powinny one przysłonić tego, co najważniejsze, czyli przyszłości. Branża szkolnictwa wyższego na całym świecie, 
w tym także w Europie i w Polsce przechodzi przez bardzo dynamiczny okres ewolucji. Przyspieszone przemiany technologiczne, nasilające się wyzwania wynikające $\mathrm{z}$ uwarunkowań demograficznych, w tym także z migracji, a jednocześnie wzrost przeciętnego poziomu dobrobytu, jak również rosnące aspiracje rozwojowe i edukacyjne wszystkich w zasadzie mieszkańców Ziemi sprawiaja, że uniwersytety, a wśród nich także Uniwersytet Ekonomiczny w Poznaniu zobowiązane sa do permanentnego redefiniowania swojej roli, poszukiwania miejsca w społeczeństwie, przy czym to ostatnie oczekuje od nich, że będą po prostu funkcjonalne i przydatne. Otoczenie społeczne uniwersytetów formułuje stale rosnace oczekiwania i wymagania, niekoniecznie przeznaczając na to stosowne i uzasadnione środki. Uniwersytety mają więc być lepsze, bardziej utylitarne, mają dawać z siebie więcej. Z drugiej strony społeczeństwo przy nasilających się wyzwaniach sektora finansów publicznych nie jest skłonne łożyć na naukę i szkolnictwo środków, które byłyby przez środowiska akademickie uważane za adekwatne. Konieczne wydaje się więc wypracowanie nowego społecznego konsensusu na temat tego, co uniwersytety robią dla społeczeństwa i co w zamian za to od tegoż społeczeństwa otrzymują. Oby nam się to udało w trakcie właśnie rozpoczętej dekady jubileuszowej.

Marian Gorynia 